regions and deprived groups for ensuring equity in access to higher education.

(This article is based on: Varghese, N.V. 2015. Challenges of massification of higher education in India, CPRHE Research Papers I, New Delhi.)

\section{Academic Freedom in the World's Largest Democracy}

\section{William G. Tierney and Nidhi S. Sabharwal}

William G. Tierney is university professor, Wilbur-Kieffer professor of higher education, and co-director of the Pullias Center for Higher Education at the University of Southern California. He currently has a Fulbright Fellowship to India. E-mail: wgtiern@usc.edu. Nidhi S. Sabharwal is associate professor in the Center for Policy Research in Higher Education at the National University of Educational Planning and Administration in New Delhi, India. E-mail: nidhis@nuepa.org.

$\mathrm{O}$ February 9, 20I6, a cultural program was held on the campus of Jawaharlal Nehru University (JNU) in the heart of New Delhi, India. JNU, largely a graduate institution with 8,000 students, is thought of as one of India's best universities. The faculty and students have the reputation of being from the left and vocal in opposition to the current government of Narendra Modi. There is also a vocal minority of students who are members of Akhil Bharatiya Vidyarthi Parishad (ABVP), a conservative organization closely allied with the Rashtriya Swayamsewak Sangh (RSS), another ultra-conservative Hindu nationalist group.

The event was organized by the Democratic Student Union and initially approved by the administration. The ABVP protested, however, and the administration cancelled the event. The students nevertheless went ahead with what they defined as a cultural program. The program's purpose was to commemorate through poetry, music, and art- the death of Afzal Guru, the terrorist convicted of bombing Parliament in 200I. The organizers also talked about the ongoing struggles in Kashmir, the rights of the people in the region, and the importance of self-determination. Kanhaiya Kumar, the president of the Student Union, attended the event in support.

Three days after the event, the vice chancellor let the police enter the campus and arrest Kanhaiya Kumar for sedition. Many in the country believed that speakers crossed a line by talking about Kashmir in a manner that suggested independence.

\section{Attacking the Country or Attacking Academic FREEDOM?}

The actions on and off campus have been front page news for two months. Those on the right have condemned the protest. The Home Minister of India stated, "If anyone raises anti-India slogans, tries to raise questions on the country's unity and integrity, they will not be spared." Some have argued for violence against anyone who would speak against the country; others have said the university should be shut down-that such events should never be allowed at a public university. The High Court judge who granted bail to Kanhaiya said that "the entire JNU campus suffers from some unpatriotic and anti-national infestation that requires cleansing through pro-active policing."

Others have suggested that Kanhaiya's arrest and the ensuing outcry is yet another attack on academic freedom. Since the Modi government came to power in 20I4, over 50 intellectuals have returned their medals and awards in part to protest a crackdown on academic freedom at India's universities. Others allege that a stifling of academic freedom has been behind the government's multiple forced resignations from academic and intellectual committees and organizations. Recent appointments of the Chair of the National Book Trust, the Central Advisory Board of Education, and the Indian Council of Historical Research, are examples of individuals and bodies who fall in line with the current government's policies; those who were purged from those positions were respected academics who did not necessarily agree with one or another policy of the government. Many argue that such actions have not been uncommon in the past as well.

\section{Framing Academic Freedom}

Such issues underscore the tensions of academic freedom. Except for ideologues, academic freedom is an elusive concept whose meanings and interpretations require thoughtful consideration. India is a democracy, but its definitions, for example, of what counts as sedition differs from another democracy such as the United States. The sorts of movies and books that get censored in India reflect an environment that is more conservative than in the United States. A new movie, Aligarh, depicts a relationship between a male professor and a (male) rickshaw driver. Largely based on the true story of an academic who committed suicide, the movie cannot find a broad outlet in India; numerous groups have tried to ban the movie from being seen on the campus where the professor worked. Is academic freedom a cultural term that requires a common understanding, or does the locale of the university circumscribe its meaning? The curricula in India's postsecondary classrooms are largely prescribed. Is the Indian historian and public intellectual, Romila Tharpar, correct that standardized syllabi that are 
centrally controlled are an infringement on academic freedom and an example of a "totalitarian society"?

\section{Academic Freedom Inside and OUtside of the Class- ROOM}

Generally, discussions of academic freedom divide in two. On the one hand, what the academic says in the classroom and pertains to his or her specific research helps us understand what one can say, because the individual speaks and writes from a particular knowledge base. On the other hand, extramural speech defines what a professor might say outside of the classroom, where he or she claims no disciplinary expertise. Both areas have become points of contention.

Communicating an idea in a classroom that others disagree with, may lead to the termination of one's services and the elimination of a text. Rohinton Mistry's Booker Prize shortlisted novel, Such a Long Journey, for example, was eliminated from a syllabus when a student objected to certain passages. The novel tells the story of a bank clerk who belongs to Mumbai's Parsee community. A few pages in the novel negatively portray Indian politics and a specific political party. As an act of self-censorship, Mumbai University removed the book from its reading lists. Similarly, a professor at Banaras Hindu University was fired when he tried to screen in his Development Studies class the currently banned India's Daughter, a movie about a rape that occurred in New Delhi.

\section{Rightly framed, these sorts of discus- sions can be useful in helping academ- ics to think through thorny issues that go to the heart of what a nation wants of its universities.}

The kind of events that transpired at JNU is what has provoked heated discussions about academic freedom. The challenge of what should be taught in the classroom extends to the sorts of seminars, clubs, and activities that occur outside of the classroom. The JNU Centre for Sanskrit Studies invited, for example, a well-known Yoga Guru for a keynote address in an academic seminar. The individual is looked on as supportive of the conservative government. A group of students opposed the invitation, terming it as a "silent right-wing onslaught." The speaker felt obliged to cancel his keynote.

\section{CONCLUSION}

Some will suggest that to critique academic freedom in In- dia today requires an understanding of academic freedom in India a generation ago. In essence, they are asking if today's concerns about academic freedom are simply a way to criticize the Modi government and portray its members as conservative ideologues. History, to be sure, always helps us understand complex issues such as academic freedom. One also needs to ask, however, if a 28 year old student should be put in prison for 2I days because he attended an event where controversial statements were made that some define as seditious. Rightly framed, these sorts of discussions can be useful in helping academics to think through thorny issues that go to the heart of what a nation wants of its universities.

\section{The "New" Private Higher Education Sector in the United Kingdom}

\section{Claire Callender}

Claire Callender is professor of higher education at Birkbeck, University of London and at University College London's Institute of Education, where she is deputy director and coinvestigator at the Centre for Global HigherEducation (CGHE).E-mail: c.callender@bbk.ac.uk.

$\mathrm{D}$ eveloping a private higher education sector in England-euphemistically called "alternative providers"is central to the UK government's policies. The government already allows students enrolled on approved courses at private providers to claim government-subsidized financial aid. Since 2010 , it has made it easier for private colleges to enter the higher education undergraduate market through liberalization. It plans to do much more. The government's 2015 higher education Green Paper, shortly to be turned into legislation, wants to remove barriers to entry and growth. In return for more regulation and potentially much more money, it proposes speeding up the processes whereby new entrants can gain degree awarding powers and access a university title, while simultaneously lowering the entry bar. Why is the government pushing this policy agenda? Does England need a private higher education sector?

To date, there is absolutely no evidence that UK private providers are really challenger institutions or disruptive innovators who will reshape the higher education undergraduate market, improve quality, widen participation, and drive down prices. Rather they are costly to the public purse, divert resources away from existing public provision, absorb an inordinate amount of public officials' time, en- 